\section{Keeping up with the latest trends}

\section{David Cove}

Trends in Genetics: DNA, Differentiation \& Development. Editor Alison Stewart. Elsevier. 12/yr. Dfl. 500 (institutional); Dfl. 150, $£ 33, \$ 57$ (individual).

THIs journal follows the traditions of excellence which were rapidly established by its sister journal, Trends in Biochemical Sciences. The principal content of each issue is a number of brief, commissioned reviews of topics of current interest in genetics. As its subtitle suggests, most of the reviews are in the molecular and developmental areas, but the scope of some is a good deal wider; in particular, the evolutionary implications of recent findings get deserved emphasis.

The reviews show a consistently high standard of writing, are commendably up to date and, in general, are similar to the equally high-quality reviews which appear in Cell. Each is only a few pages long, and therefore necessarily limited in scope, but most give references which quickly lead the reader to further, more detailed or both for established scientists, to help them keep abreast of developments in fields distant from their own, and for students where they will provide a way into topics that are to be studied in greater depth. broader articles. They are therefore ideal

In the "Perspectives" section a number of articles have appeared which are midway between reviews and essays. These allow the author more licence to put forward personal ideas, and I found some of them very stimulating and enjoyable. A limited number of papers, dealing with historical aspects of genetics, appears under the heading of "Retrospectives". Perhaps it is a sign of my age, but I enjoyed these too, particularly a two-part article on Thomas Hunt Morgan.

Each issue also contains sections entitled "Monitor", which has much the same aims as "News and Views" in Nature, although it of course concentrates on

\section{TRENDS IN GENETICS}

genetical and developmental topics, and "Technical Tips" which provides an opportunity for the publication of (unsolicited) information on experimental techniques. Finally book reviews, correspondence and "Genetic Jottings" are included, the latter providing a notice board for information on courses, meetings and workshops.

This journal should prove invaluable to all students and researchers in molecular and developmental genetics. It can also be recommended to non-specialists, as the reviews attempt to keep to a minimum the amount of background knowledge required to understand them.

David Cove is Professor in the Department of Genetics, University of Leeds, Leeds LS2 9JT, UK.

\section{Down to earth}

\section{Richard G. Burns}

Soil Use and Management. Editor A Wild. Blackwell Scientific. 4/yr. UK £37, North America and Japan \$72, elsewhere $£ 44.50$ (institutional); UK £28, North America and Japan \$55, elsewhere $\$ 33.50$ (individual).

Biology and Fertility of Soils. Editor-inchief J.C.G. Ottow, Springer-International. 8/yr in 2 volumes. DM 490.

I'M SURE that I am not alone in experiencing a sinking feeling whenever a new journal is announced. It is difficult enough keeping up with the existing literature without the addition of yet another batch of papers. Despite such misgivings fresh contenders for a slice of library budgets continue to appear, and 1985 saw the debut of two quarterly, A4-size journals in the general area of soil science.

The first, Soil Use and Management, is a British Soil Science Society publication edited by Professor Alan Wild at the University of Reading. Its intention is to com- most journals, I'm more worried that the readership of Soil Use and Management will be limited by a decision to restrict the journal's emphasis to temperate-zone agriculture. This is reflected in the papers, the vast majority of which come from Britain. I would like to see the journal becoming more international in its coverage and encouraging papers on such topics as arid zone and tropical agriculture. In many ways British agricultural science has been too successful for its own good (witness the drastic surgery now being applied to AFRC institutes) and it needs to look outwards and act as a guiding influence in Third World agriculture. I hope that Soil Use and Management will evolve to be a force in this. For the moment, however, the journal has made an encouraging if rather introverted start.

Biology and Fertility of Soils is a rather different publication. When it was first mooted most soil biologists that I spoke to couldn't conceive of a niche for it since the subject matter is exactly of the type covered by two established high-quality journals, Soil Biology and Biochemistry and Plant and Soil. A few cynically suggested that it might prove to be a dumping-ground for rejected papers. However, for prospective contributors new journals often have an important advantage over established ones in that they publish comparatively rapidly (not particularly fast at around 6-8 months for Biology and Fertility of Soils but still somewhat better than its older rivals). The editor, J.C.G. Ottow of the University of Hohenheim, Stuttgart, has collected a large and august editorial board and thus ensured an early supply of papers from famous name authors - these are generally not throw-aways either, but good and thought-provoking articles.

The journal encourages papers in four overlapping areas: soil biology, soil fertility, soil hygiene and soil biotechnology, and has a strong international flavour with some 14 countries being represented in the first volume. There are about eight original papers per issue and some reviews are promised. A future issue will be devoted to a single topic, namely the effects of inoculation with associative nitrogenfixing bacteria on plant growth: a stimulating and controversial subject if ever there was one! The quality of production is high with the notable exception of the figures, many of which are poor - tighter control is needed here.

Overall, Biology and Fertility of Soils has surprised its doubters by making an auspicious start, and I'm sure that many departments will be looking for ways to subscribe to it. In the meantime it will be a frequently-requested item through interlibrary loans.

Richard G. Burns is a Senior Lecturer in the Biological Laboratory, University of Kent, Canterbury, Kent CT2 7 NJ, UK. 